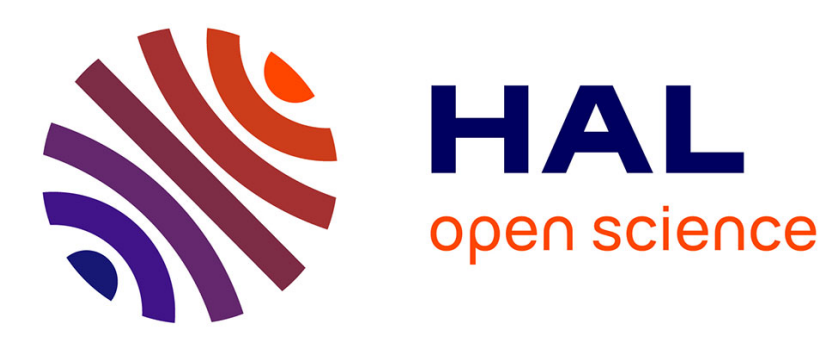

\title{
EdU Incorporation for FACS and Microscopy Analysis of DNA Replication in Budding Yeast
}

\author{
Nicolas Talarek, Julie Petit, Elisabeth Gueydon, Etienne Schwob
}

\section{To cite this version:}

Nicolas Talarek, Julie Petit, Elisabeth Gueydon, Etienne Schwob. EdU Incorporation for FACS and Microscopy Analysis of DNA Replication in Budding Yeast. Sonya Vengrova; Jacob Dalgaard. DNA Replication. Methods and Protocols, 1300, Springer, pp.105-112, 2015, Methods in Molecular Biology, 978-1-4939-2596-4. 10.1007/978-1-4939-2596-4_7 . hal-02134956

\section{HAL Id: hal-02134956 https://hal.science/hal-02134956}

Submitted on 28 May 2019

HAL is a multi-disciplinary open access archive for the deposit and dissemination of scientific research documents, whether they are published or not. The documents may come from teaching and research institutions in France or abroad, or from public or private research centers.
L'archive ouverte pluridisciplinaire HAL, est destinée au dépôt et à la diffusion de documents scientifiques de niveau recherche, publiés ou non, émanant des établissements d'enseignement et de recherche français ou étrangers, des laboratoires publics ou privés. 


\section{EdU incorporation for FACS and microscopy analysis of DNA replication in budding yeast.}

Nicolas Talarek, Julie Petit, Elisabeth Gueydon and Etienne Schwob.

Running title: Improved cell cycle analysis in S. cerevisiae using EdU

\section{Summary}

DNA replication is a key determinant of chromosome segregation and stability in eukaryotes. The yeast Saccharomyces cerevisiae has been extensively used for cell cycle studies, yet simple but key parameters such as the fraction of cells in S phase in a population or the subnuclear localization of DNA synthesis have been difficult to gather for this organism. 5ethynyl-2'-deoxyuridine (EdU) is a thymidine analogue that can be incorporated in vivo and later detected using copper-catalysed azide alkyne cycloaddition (Click reaction) without prior DNA denaturation. This chapter describes a budding yeast strain and conditions that allow rapid EdU incorporation at moderate extracellular concentrations, followed by its efficient detection for the analysis of DNA replication in single cells by flow cytometry and fluorescence microscopy.

Key words: S. cerevisiae, yeast, TK-hENT1, DNA replication, EdU, pulse-labelling, Click reaction, bivariate FACS, microscopy, replication foci, cell cycle.

\section{Introduction}

The in vivo incorporation of radiolabelled or halogenated thymidine analogues has long been used for studying the proliferation and kinetics of DNA replication in mammalian cells (1). This requires uptake of extracellular thymidine followed by its phosphorylation to dTMP by thymidine kinase (TK), which yields to dTTP that is used by DNA polymerases. Neither budding nor fission yeast, two prominent model organisms for cell cycle studies, are naturally able to incorporate exogenous thymidine analogues due to their lack of thymidine kinase. To circumvent this problem, yeast strains have been engineered to incorporate exogenous bromo-deoxyuridine (BrdU), or other thymidine analogues, by the forced expression of herpes simplex virus TK $(2,3)$ and human equilibrative nucleoside transporter hENT1 (4-8). BrdU-substituted DNA is detected in various analytical methods $(6,9,10)$ using anti-BrdU antibodies. However these antibodies will recognize their antigen only if DNA is single-stranded or denatured, and penetrate cells only if they are permeabilized and devoid of their cell wall. This has some impractical consequences, mainly the loss of cell ultrastructure due to the harsh denaturing conditions and the near impossibility to perform FACS analysis because yeast spheroplasts lyse in hypotonic solutions.

EdU (5-ethynyl-2'-deoxyuridine) is a thymidine analogue that is incorporated in vivo using the same route as BrdU. EdU contains an alkyne moiety that can be chemically coupled to azide-modified fluorochromes via selective Click reaction (11). EdU detection does not require DNA denaturation and the fluorescent reagent is small enough to traverse the yeast cell wall, making spheroplasting dispensable (9). Methods for the detection of EdU by FACS and microscopy have been described in fission yeast, but the elevated EdU concentrations and long incubation times used were shown to activate the DNA damage response, limiting their usefulness in studying physiological DNA replication (12,13).

This chapter describes a budding yeast strain harbouring stably integrated cassettes expressing high levels of thymidine kinase and nucleoside transporter, which allow fast and efficient EdU uptake and incorporation. Using these strains and the protocols provided below, it is possible to detect and quantitate EdU-substituted DNA after incubating cells with low doses of EdU that do not interfere with cell proliferation. Moreover brief exposure to higher doses of EdU allows to determine, using bivariate EdU-PI FACS analysis and fluorescence microscopy, the fraction of cells in S phase in exponentially growing cultures as well as the duration and subnuclear localization of DNA replication in single cells.

Using the methods described here, cell cycle progression and chromosome replication can be studied in budding yeast with much better spatial and temporal resolution than previously. For instance, it is 
possible, using short EdU pulses ( $3 \mathrm{~min}$ ) on synchronized cultures, to determine precisely when DNA replication begins and finishes, which is impossible by traditional FACS measurements of DNA content. With this method it became clear that bulk DNA synthesis is already finished in cells with small buds. The Click reaction being highly efficient and selective, the rate of DNA synthesis can also be determined by quantifying the levels of EdU fluorescence in single cells. Finally, it is now possible to determine easily by cytometry the fraction of cells in $\mathrm{S}$ phase in a population and thus address whether particular mutants accumulate in the G1, S or G2+M phase of the cell cycle. Moreover, by calculating the doubling time of these cells, one can extrapolate the absolute duration of cell cycle phases. We expect these methods to greatly improve the phenotypic characterization of many yeast mutants

\section{Materials}

\subsection{Yeast culture, labelling and fixation}

1. Yeast E3087: MATa, URA3::GPD-TK 5 , AUR 1c::ADH-hENTI (W303 RAD5).

2. SC-D medium (synthetic complete + dextrose): $2 \mathrm{~g} / \mathrm{L}$ Yeast nitrogen base (w/o amino acids, w/o $\mathrm{NH}_{4} \mathrm{SO}_{4}$ ), $5 \mathrm{~g} / \mathrm{L}$ ammonium sulphate, autoclaved and supplemented with $20 \mathrm{~mL} / \mathrm{L}$ filter sterilized 50x AAA mix (10 g/L threonine, $5 \mathrm{~g} / \mathrm{L}$ lysine, leucine, tryptophan, phenylalanine, $3 \mathrm{~g} / \mathrm{L}$ isoleucine and methionine, $2.5 \mathrm{~g} / \mathrm{L}$ histidine, adenine and uracil, $2 \mathrm{~g} / \mathrm{L}$ arginine) and $2 \%$ glucose (see Note 1).

3. EdU (5-ethynyl-2'-deoxyuridine) $10 \mathrm{mM}$ in DMSO, stored in aliquots at $-20^{\circ} \mathrm{C}$

4. $20 \%$ paraformaldehyde (PFA), dissolved in water by heating up to $70^{\circ} \mathrm{C}$ with $0.2 \mathrm{~mL} \mathrm{NaOH}$ $10 \mathrm{~N}$ per $10 \mathrm{~mL}$. Can be stored a few days at $4^{\circ} \mathrm{C}$.

5. $100 \%$ ethanol

6. Phosphate buffer saline (PBS): $137 \mathrm{mM} \mathrm{NaCl}, 2.7 \mathrm{mM} \mathrm{KCl}, 4.3 \mathrm{mM} \mathrm{Na}_{2} \mathrm{HPO}_{4}, 1.47 \mathrm{mM}$ $\mathrm{KH}_{2} \mathrm{PO}_{4}, \mathrm{pH} 7.5$. Autoclave and store at room temperature.

7. $10 \%$ ethanol in PBS.

8. Rocking platform or microtube mixer.

\subsection{Click reaction for FACS analysis}

1. $0.2 \mathrm{M} \mathrm{CuSO}_{4}$.

2. $1 \mathrm{M}$ ascorbic acid.

3. $2 \mathrm{mM}$ Alexa 647 -azide (Invitrogen) or disulfo-Cy5 azide (CyanDye) in DMSO

4. PBS, pH 7.5 (Subheading 2.1 item 6).

5. $100 \%$ ethanol.

6. $10 \mathrm{mg} / \mathrm{mL}$ RNAse A, boiled.
7. $20 \mathrm{mg} / \mathrm{mL}$ proteinase $\mathrm{K}$.

8. $\mathrm{PBS}+1 \%$ bovine serum albumin (BSA)

9. $5 \mathrm{mM}$ Sytox Green.

10. $1 \mathrm{mg} / \mathrm{mL}$ propidium iodide $(\mathrm{PI})$

11. $50 \mathrm{mM}$ Tris- $\mathrm{HCl}, \mathrm{pH} 7.5$.

12. Sonicator (VibraCell 72405 or equivalent)

13. FACS Calibur or equivalent flow cytometer with $488 \mathrm{~nm}$ and 635 laser lines.

\subsection{Click reaction for microscopy analysis}

1. $0.2 \mathrm{M} \mathrm{CuSO}_{4}$.

2. $1 \mathrm{M}$ ascorbic acid.

3. $2 \mathrm{mM}$ Dy-530 azide (Dyomics) in DMSO.

4. $\mathrm{PBS}+1 \% \mathrm{BSA}$

5. $100 \%$ ethanol.

6. $0.5 \mu \mathrm{g} / \mathrm{mL}$ 4',6-diamidino-2-phenylindole (DAPI) in PBS.

7. PBS.

8. Prolong Gold anti-fade (Invitrogen).

9. Glass slides and coverslips.

10. Fluorescence microscope (Leica DM600 or equivalent) equipped with 63x HCX PL Apo 1.4-0.6 objective and CoolSnap HQ2 CCD camera.

\section{Methods}

\subsection{Yeast culture, labelling and fixation}

. Inoculate $10 \mathrm{ml}$ SC-D medium with $10^{7}$ (or less) TK-hENT1 cells (E3087) and incubate at $30^{\circ} \mathrm{C}$ until density of $\sim 10^{7}$ cells $/ \mathrm{ml}$.

2. Add EdU to the medium at final concentration $10-25 \mu \mathrm{M}$ for short pulses (5-10 min) or at 0.1-1 $\mu \mathrm{M}$ for chronic exposure (see Note 2).

3. Transfer $1 \mathrm{~mL}$ of the culture ( $10^{7}$ to $2.10^{7}$ cells) for FACS analysis and $1 \mathrm{~mL}$ for microscopy analysis to $1.5 \mathrm{~mL}$ Eppendorf tubes containing $100 \mu \mathrm{L}$ of $20 \%$ PFA, and leave for $20 \mathrm{~min}$ at room temperature (RT) to fix cells (see Note 3).

4. Add $100 \mu \mathrm{L}$ of $100 \%$ ethanol to aid cell pelleting; centrifuge for $2 \mathrm{~min}$ at $6000 \mathrm{rpm}$ in microfuge (see Note 4)

5. Discard the supernatant using a vacuum pipette and resuspend the cell pellet in $100 \mu \mathrm{L}$ of PBS. Add $350 \mu \mathrm{L}$ of $100 \%$ ethanol, mix well and leave for $\geq 1 \mathrm{hr}$ at RT on a rocking platform to permeabilize the cells (see Note 5). 
6. Pellet cells for $2 \mathrm{~min}$ at $6000 \mathrm{rpm}$ in a microfuge, discard the supernatant and wash cells twice with $500 \mu \mathrm{L}$ of $10 \%$ ethanol in PBS to remove unincorporated EdU from cells.

\subsection{Click reaction for FACS analysis}

1. Pellet cells for $2 \mathrm{~min}$ at $6000 \mathrm{rpm}$ in a microfuge, discard supernatant and resuspend pellet in $200 \mu \mathrm{L}$ of PBS containing $0.1 \mathrm{mg} / \mathrm{mL}$ of RNase A and $0.2 \mathrm{mg} / \mathrm{mL}$ of proteinase $\mathrm{K}$ (diluted 100 -fold from the stock solution). Incubate $1-2$ hours at $50^{\circ} \mathrm{C}$ with occasional shaking (or overnight at $37^{\circ} \mathrm{C}$ ).

2. Pellet cells for $2 \mathrm{~min}$ at $6000 \mathrm{rpm}$, discard supernatant and wash cells with $500 \mu \mathrm{L}$ of PBS.

3. Spin cells for $2 \mathrm{~min}$ at $6000 \mathrm{rpm}$ and resuspend cell pellet in $200 \mu \mathrm{L}$ of PBS $+1 \%$ BSA. Incubate $30 \mathrm{~min}$ at RT.

4. Spin cells for $2 \mathrm{~min}$ at $6000 \mathrm{rpm}$ and resuspend pellet in $300 \mu \mathrm{L}$ of PBS $+1 \%$ BSA Distribute between three tubes (two for Click reaction, one for Sytox Green only). Spin cells for 2 min at $6000 \mathrm{rpm}$ and discard supernatant (see Note 6).

5. For Sytox Green staining, resuspend cell pellet in 100-200 $\mu \mathrm{L}$ of PBS. Transfer $20-50 \mu \mathrm{L}$ (depending on the concentration) to a FACS tube containing $1 \mathrm{~mL}$ of $50 \mathrm{mM}$ Tris- $\mathrm{HCl}$, $\mathrm{pH}$ 7.5 and $0.5 \mu \mathrm{M}$ Sytox Green (1:10000 from stock). Leave in dark until sonication (step 10).

6. For the Click reaction, resuspend the cell pellet with $40 \mu \mathrm{L}$ of freshly made dye azide mix Per tube: $36 \mu \mathrm{L}$ of PBS, $2 \mu \mathrm{L}$ of $\mathrm{CuSO}_{4}, 0.2 \mu \mathrm{L}$ of Alexa Fluor 647 azide (or di-sulfo-Cy5 azide), $2 \mu \mathrm{L}$ of ascorbic acid. Incubate at RT in the dark for $60 \mathrm{~min}$ (see Note 7).

7. Wash cells three times with $300 \mu \mathrm{L}$ of $10 \%$ ethanol in PBS (to get rid of all soluble EdU Alexa 647 azide).

8. Resuspend cells in $100 \mu \mathrm{l}$ of $50 \mu \mathrm{g} / \mathrm{mL}$ PI in PBS; leave for $10 \mathrm{~min}$ in dark.

9. Transfer 20-50 $\mu \mathrm{L}$ to FACS tube containing $1 \mathrm{~mL}$ of $50 \mathrm{mM}$ Tris- $\mathrm{HCl}, \mathrm{pH} 7.5$.

10. Sonicate all tubes twice, $2 \mathrm{sec}$ each time at amplitude 40-50. Proceed with FACS (keep in dark until then).

11. Read the FACS samples as usual using FL1 histogram for the Sytox Green only samples, and using FL2 (x-axis) and FL4 (y-axis) dot plot for the bivariate PI-EdU readings. See Figure 1 for a typical result.

\subsection{Click reaction for microscopy analysis}

1. Spin cells for $2 \mathrm{~min}$ at $6000 \mathrm{rpm}$ in a microfuge and resuspend pellet in $200 \mu \mathrm{L}$ of PBS + $1 \%$ BSA. Incubate for $30 \mathrm{~min}$ at RT

2. Centrifuge for $2 \mathrm{~min}$ at $6000 \mathrm{rpm}$, discard the supernatant and resuspend the pellet with 40 $\mu \mathrm{L}$ of freshly made dye azide mix. Per tube: $36 \mu \mathrm{L}$ of PBS, $2 \mu \mathrm{L}$ of $\mathrm{CuSO}_{4}, 0.2 \mu \mathrm{L}$ of Dy530 azide, $2 \mu \mathrm{L}$ of ascorbic acid. Incubate at RT in the dark for $60 \mathrm{~min}$ (see Note 7)
3. Wash cells twice with $300 \mu \mathrm{L}$ of $10 \%$ ethanol in PBS (to get rid of all unreacted Dy-530 azide).

4. Resuspend cells in $100 \mu \mathrm{l}$ of $0.5 \mu \mathrm{g} / \mathrm{mL}$ DAPI in PBS; leave for $30 \mathrm{~min}$ in dark.

5. Spin, wash with $300 \mu \mathrm{L}$ of PBS to remove excess DAPI; spin and resuspend pellet with 10$50 \mu \mathrm{L}$ of PBS depending on cell concentration (see Note 8).

6. Pipette $1.7 \mu \mathrm{L}$ of cells onto glass slide and cover with clean coverslip; observe immediately on fluorescence microscope with DAPI and Cy-3 filters. See Figure 2 for a typical result (see Note 9).

\section{Notes}

1. E3087 cells can also be grown in rich (YEPD) medium if EdU-substituted DNA is purified afterwards. However, we found that the Click reaction works much better, when performed on cells, if the latter are grown in SD or SC medium.

2. EdU is more toxic than BrdU for TK-hENT1 cells. The viability of E3087 cells, measured by drop test on YPD plates at $30^{\circ} \mathrm{C}$, decreases at EdU concentrations $\geq 10 \mu \mathrm{M}$ (compared to $\geq 100 \mu \mathrm{M}$ for BrdU). The growth of cells expressing either TK or hENT1 alone is unaffected by $100 \mu \mathrm{M}$ EdU. E3087 cells grown in the presence of 0.1 to $1.0 \mu \mathrm{M}$ EdU for 1-3 generations have a doubling time identical to wild type, yet contain enough EdU for detection by microscopy and FACS. Avoid direct light exposure of cells having incorporated EdU.

3. Fixation with $2 \% \mathrm{PFA}$ at RT is better than putting cells on ice, since the latter causes microtubule depolymerisation and loss of nuclear architecture in mitotic cells.

4. Cells grown in SC medium tend to stick to the walls of Eppendorf tubes, and do not pellet well. Adding 10\% ethanol improves pelleting and reduces cell loss.

5. Cell permeabilization is required both to get rid of the unincorporated EdU and to let the fluorescent azide penetrate cells. Cells can be stored for several days at $-20^{\circ} \mathrm{C}$ at this stage.

6. The Click reaction with $\mathrm{CuSO}_{4}$ and ascorbic acid quenches considerably the Sytox Green and PI fluorescences, which can distort the reading of DNA content. It is therefore strongly advised to take an aliquot for Sytox Green staining (without Click), for a reference profile.

7. Reagents for the Click reaction have to be added in the indicated order. However when working with several samples it is possible to prepare a master mix for all tubes, which is then dispatched to each sample tube.

8. Cells can be kept at this stage for a few days at $4{ }^{\circ} \mathrm{C}$, or at $-20^{\circ} \mathrm{C}$ for longer periods.

9. The EdU and DAPI signals are sufficiently strong and stable for direct scoring. However for longer exposures and quantification of EdU signal, it is advised to add anti-fading agents such as p-phenylene-diamine $(1 \mathrm{mg} / \mathrm{mL})$ or mount cells in ProLong Gold and let cure overnight. 


\section{Acknowledgments}

We are grateful to Katsuhiko Shirahige for providing the yeast codon optimized hENT1 integration plasmid, and the Montpellier RIO Imaging facility for help with microscopy and cytometry. NT holds a post-doctoral fellowship from the Association pour la Recherche sur le Cancer (ARC), JP was funded by doctoral fellowships from the Région Languedoc-Roussillon and ARC. ES thanks ARC, Cancéropôle Grand Sud-Ouest and CNRS for laboratory funding.

\section{References}

1. Dolbeare, F. (1996) Bromodeoxyuridine: a diagnostic tool in biology and medicine, Part III. Proliferation in normal, injured and diseased tissue, growth factors, differentiation, DNA replication sites and in situ hybridization. Histochem J. 28, 531-575.

2. McNeil, J.B., and, Friesen J.D. (1981) Expression of the Herpes simplex virus thymidine kinase gene in Saccharomyces cerevisiae. Mol Gen Genet. 184, 386-393.

3. Lengronne, A., Pasero, P., Bensimon, A., and Schwob, E. (2001) Monitoring S-phase progression globally and locally using BrdU incorporation in TK(+) yeast strains. Nucleic Acids Res. 29, 14331442.

4. Vernis, L., Piskur, J., and Diffley, J.F. (2003) Reconstitution of an efficient thymidine salvage pathway in Saccharomyces cerevisiae. Nucleic Acids Res. 31, e120.

5. Hodson, J.A., Bailis, J.M., and Forsburg, S.L. (2003) Efficient labeling of fission yeast Schizosaccharomyces pombe with thymidine and BUdR. Nucleic Acids Res. 31, e134.

6. Sivakumar, S., Porter-Goff, M., Patel, P.K., Benoit, K., and Rhind, N. (2004) In vivo labeling of fission yeast DNA with thymidine and thymidine analogs. Methods. 33, 213-9.

7. Terasawa, M., Ogawa, H., Tsukamoto, Y., Shinohara, M., Shirahige, K., Kleckner, N., and Ogawa, T. (2007) Meiotic recombination-related DNA synthesis and its implications for crossover and non-cross-over recombinant formation. Proc. Natl. Acad. Sci. U S A. 104, 5965-5970.

8. Schwob, E., de Renty, C., Coulon, V., Gostan, T., Boyer, C., Camet-Gabut, L., and Amato, C. (2009) Use of DNA combing for studying DNA replication in vivo in yeast and mammalian cells. Methods Mol. Biol. 521, 673-687.

9. Bianco J.N., Poli, J., Saksouk, J., Bacal, J., Silva, M.J., Yoshida, K., Lin, Y.L., Tourrière, H., Lengronne, A., and Pasero, P. (2012) Analysis of DNA replication profiles in budding yeast and mammalian cells using DNA combing. Methods 57, 149-157.

10. Poli, J., Tsaponina, O., Crabbé, L., Keszthelyi, A., Pantesco, V, Chabes, A., Lengronne, A., Pasero, P. (2012) dNTP pools determine fork progression and origin usage under replication stress. EMBO J. 31, 883-894.
11. Salic, A., and Mitchison, T.J. (2008) A chemical method for fast and sensitive detection of DNA synthesis in vivo. Proc. Natl. Acad. Sci. U S A. 105, 2415-2420.

12. Hua, H., and Kearsey, S.E. (2011) Monitoring DNA replication in fission yeast by incorporation of 5-ethynyl-2'-deoxyuridine. Nucleic Acids Res. 39, e60.

13. Sabatinos, S.A., Mastro, T.L., Green, M.D., and Forsburg, S.L. (2013) A mammalian-like DNA damage response of fission yeast to nucleoside analogs. Genetics 193, 143-157.

\section{Figure captions}

Figure 1: FACS analysis of exponentially growing TK-hENT1 (E3087) cells in SC-D medium at $30^{\circ} \mathrm{C}$ and pulsed for 5 min with $25 \mu \mathrm{M}$ of EdU. A) Bivariate EdU Alexa 647 versus propidium iodide dot plot showing the percentage of cells in G1, S and G2+M phases of the cell cycle. Note that $\mathrm{y}$-axis is in $\log$ scale. B) Sytox Green histogram of the same sample.

Figure 2: Wide-field microscopy image of TK-hENT1 (E3087) cells growing in SC-D at $30^{\circ} \mathrm{C}$ and pulsed for 3 min with EdU at $25 \mu \mathrm{M}$ (final concentration). The Click reaction was performed with Dy530 azide (red), nuclei were counterstained with DAPI (green) and cells visualized by DIC (grey). Note that DNA synthesis takes places in cells with tiny or no buds, and is largely completed in cells with small buds. 